\title{
GPI Gene
}

National Cancer Institute

\section{Source}

National Cancer Institute. GPI Gene. NCI Thesaurus. Code C26590.

This gene plays a role in glycolysis, gluconeogenesis and energy pathways. 